\title{
Physicochemical properties of tarap (Artocarpus adoratisimus) starch
}

\author{
${ }^{1}$ Noorfarahzilah, M., ${ }^{1}$ Jau-Shya, L., ${ }^{1}$ Mansoor, A.H., ${ }^{1}$ Jahurul, M.H.A., ${ }^{1}$ Umi Hartina, M.R., \\ ${ }^{2}$ Zainol, M.K., and ${ }^{1,{ }^{*}}$ Hasmadi, M. \\ ${ }^{1}$ Faculty of Food Science and Nutrition, Universiti Malaysia Sabah, 88400 Kota Kinabalu, Sabah, Malaysia \\ ${ }^{2}$ School of Food Science and Technology, Universiti Malaysia Terengganu, 21030 Kuala Terengganu,
} Terengganu, Malaysia

\begin{abstract}
Article history:
Received: 13 October 2019

Received in revised form: 28

November 2019

Accepted: 30 November 2019

Available Online: 17

December 2019
\end{abstract}

\section{Keywords:}

Tarap,

Artocarpus,

Starch,

Pasting,

Gelatinization,

Retrogradation

DOI:

https://doi.org/10.26656/fr.2017.4(3).337

\begin{abstract}
The objective of the research was to investigate the physicochemical characteristics of Tarap fruit starch. In this study, young Tarap fruit starch was extracted and the percentage of total starch, resistant starch, amylose and amylopectin were determined. Scanning electron microscope was used to evaluate the morphological features of the starch granule. Swelling, pasting, gelatinization, retrogradation and in vitro digestibility were also investigated. A total of $17.85 \%$ starch was successfully extracted from unripe Tarap fruit, whereas the amount of total starch and resistant starch were $89.14 \%$ and $47.82 \%$, respectively. The amounts of rapid digestible starch and slowly digestible starch were $6.58 \%$ and $23.25 \%$, respectively. Results found that the amylopectin content was higher than amylose $(77.15 \%$ and $11.97 \%)$. The starch granules were round and polygon in shapes with smooth surfaces. The average of starch granules size was range from 6.50 to $8.30 \mu \mathrm{m}$ with $7.4 \mu \mathrm{m}$ of mean granule diameter. Pasting properties showed that peak viscosity was observed at about $6.5 \mathrm{~min}$ at $73.5^{\circ} \mathrm{C}$. Tarap starch gelatinization temperatures (onset, $71.63^{\circ} \mathrm{C}$; peak, $74.56^{\circ} \mathrm{C}$; conclusion, $78.24^{\circ} \mathrm{C}$ ) and enthalpy of gelatinization $\left(\Delta \mathrm{H}_{\text {gel }}\right)(3.74 \mathrm{~J} / \mathrm{g})$ were higher while the retrograded starches show lower retrogradation temperature and enthalpy than native starches. Unripe Tarap starch showed good potential to be utilized as adhesives and thickener for industrial applications.
\end{abstract}

\section{Introduction}

Tarap fruit is a native fruit in Sabah, Malaysia. Botanically it is known as Artocarpus odoratissimus and belongs to the Moraceae plant family. From a morphology perspective, the fruit can be regarded as an intermediate shape between the jackfruit and breadfruit. Their flesh and seed are such a potential food source but they are not fully exploited (Noorfarahzilah et al., 2017). It is reported that Tarap fruits are rich in phenolic compounds that may contribute to the health benefit when consumed (Abu Bakar et al., 2009). Due to the high carbohydrate content $(76.8 \%)$ in the pulp, Tarap fruits can be a valuable source of starch. Past research showed that substantial efforts have been made to obtain starches from non-conventional sources to be used in food application. There is a growing tendency towards finding alternative sources of starch from novel and underutilized starch varieties rather than relying on known starch cultivars (Adebowale et al., 2005; Nwokocha and Williams, 2011; Rengsutthi and
Charoenrein, 2011).

Starch is an abundant source of energy stored in plants and it is the second largest biomass after cellulose. Lately, the growing commercial value of starch is due to demand by large industry, small and medium enterprises as a source of raw material in the manufacture of food, cosmetics, paper, textile and pharmaceutical (Vaclavik and Christian, 2008; Othaman et al., 2010). The use of starch in the food industry is expanding, particularly in the production of food products that act as a thickener, stabilizing agent and also provide a good product texture. This prompted more studies focusing on nonconventional starch carried out in an effort to diversify its sources of starch from local agricultural products that can be commercialized. Identification of native starch sources is required for desired functionality and unique properties. The physicochemical properties and functional characteristics that are impacted by the starches to the aqueous systems and their uniqueness in various food applications vary with the biological origin 
(Svegmark and Hermansson, 1993).

It is well known that starch is composed of a mixture of two distinct macromolecules, namely amylose and amylopectin, where both the granules vary in size and molecular structure. The difference in the two macromolecular structures affects the functional features such as starch pasting viscosity, elasticity and strength of the gel, and its gelatinization temperature (Jane et al., 1999; Tattiyakul et al., 2007). Application in the starch industry is dependent on the functional characteristics of starch, which vary according to botanical resources (Yuan et al., 2007; Wickramasinghe et al., 2009) as well as influenced by the shape and structure of starch molecules (Wang and White, 1994).

Additionally, in terms of nutrition, starches are classified on the basis of their rate and extent of digestion into three categories; rapidly digestible starch (RDS), slowly digestible starch (SDS) and resistant starch (RS). Resistant starch is defined as the fraction of starch in foods that are resistant to digestive enzymes (Haralampu, 2000), cannot be digested in the small intestine, but may be fermented in the large intestine (Englyst et al., 1992). Englyst et al. (1992) defined RDS as the starch fraction that causes a rapid increase in blood glucose level after ingestion, indeed SDS is the starch fraction that is digested slowly but completely in the human small intestine which is good in stable glucose metabolism, diabetes management, mental performance, and satiety (Lehmann and Robin, 2007). However, starch digestibility is largely ascribed to the plant source and is dependent on the physicochemical properties of the starch. Thus, the exploration of the nutritional value of starch in food is very important in order to increase the production of functional food products that have added value especially in terms of health improvement.

Furthermore, there is still no information and/or any research related on the physicochemical properties of Tarap fruit starch in Sabah, Malaysia. Hence, this study was undertaken to identify the characteristics of the physicochemical young Tarap fruit starch content including the total starch, resistant starch, and in vitro starch digestibility, amylopectin/amylose content, swelling capacity, starch granule morphology, pasting properties, and thermal properties. It is hoped that the data generated from this study will complement the search for novel starch sources which will be useful for food industrial applications.

\section{Materials and methods}

\subsection{Materials}

The unripe fruits of $A$. odoratissimus were collected from different locations (Sipitiang, Kota Marudu and
Tenom) in Sabah, Malaysia during September November 2012 (fruit seasoning).

\subsection{Isolation of Tarap fruit starch}

Tarap fruit starch was isolated using the method described by Agboola et al. (1991) with some modifications. The grated pulp was suspended in $5 \mathrm{~L}$ of distilled water for $12 \mathrm{hrs}$ to allow the starch to come out of the pulp. The suspended pulp was sieved using a muslin cloth with retained fibre. The fibre was rewashed to remove adhering starch. The extracted starch was allowed to sediment for 4 hours, the supernatant was decanted off and the starch washed with $5 \mathrm{~L}$ of distilled water twice to remove proteins and fibre and finally sediment for another $4 \mathrm{hrs}$. The supernatant was then decanted. The sediment was washed with water three times. The slurries were centrifuged at $2,000 \times \mathrm{x}$ for 15 mins at $4^{\circ} \mathrm{C}$. The supernatant was drained and the upper brown sediment was scraped and the remaining was washed with distilled water for 3 times and centrifuged at $2,000 \times g$ for $15 \mathrm{mins}$ at $4^{\circ} \mathrm{C}$. Finally, the extracted starch then dried using hot air at $40^{\circ} \mathrm{C}$ for 12 hrs. The dried starch was grounded with a mortar and passed through a sieve $(0.15 \mathrm{~mm}$ mesh size $)$, packaged in an air-tight container until further analysis.

\subsection{Morphological characteristics of starch granules}

The starch sample was mounted on a scanning electron microscopy (SEM) stub with double-sided adhesive tape and coated with gold. Scanning electron micrographs were taken with a JEOL JSM-5600LV microscope (JEOL, England). The average of granule size was determined by using the width and length of 300 granules from SEM micrograph.

\subsection{Total starch}

The total starch was determined using the total starch Megazyme assay kit, a total starch assay kit based on the use of thermostable a-amylase and amyloglucosidase (Megazyme International Ireland Limited, Wicklow, Ireland) (McCleary et al., 1997) and this method has been adopted by AOAC (Method 996.11) and AACC (Method 76.13).

\subsection{Amylose/Amylopectin content}

Amylose and amylopectin content were determined using Megazyme Amylose/Amylopectin Assay kit (Megazyme International Ireland Limited, Wicklow, Ireland).

\subsection{Resistant starch}

Resistant starch content was determined by a Megazyme Resistant Starch Assay Kit (AOAC Method. 
2002.02) (McCleary et al., 2002).

\subsection{In vitro digestibility starch}

In vitro starch digestibility was analysed following the method described by Englyst et al. (1992) as modified by Chung et al. (2006). The glucose released was measured using a glucose oxidase-peroxidase (GOPOD) reagent kit (K-GLOX, Megazyme Bray, Co. Wicklow, Ireland) by absorbance at $510 \mathrm{~nm}$ against the reagent blank. This was then converted into starch by multiplying the amount of glucose by 0.9 . The rate of starch digestion was expressed as a percentage of the total starch hydrolysed at different times $(30,90,120$ mins). The 30 and 120-min hydrolysis represented the rapidly digestible starch (RDS) and slowly digestible starch (SDS) respectively (Rosin et al., 2002). The equation by Rashmi and Urooj (2003) was adopted for the calculation of starch digestion Index (SDI) $=$ RDS/ TS X100.

\subsection{Starch swelling power}

Starch $(0.1 \%, \mathrm{w} / \mathrm{w}$, dry basis) was dispersed in distilled water by means of a magnetic stirrer. Dispersion aliquots $\left(\begin{array}{llll}10 & \mathrm{~g}\end{array}\right)$ containing $1 \mathrm{mg} / \mathrm{mLstarch}$ was transferred into pre-weighed tubes, sealed and immersed in a thermostatic water bath equipped with a mechanical shaker for 30 mins from $60^{\circ} \mathrm{C}$ to $90^{\circ} \mathrm{C}$ at $10^{\circ} \mathrm{C}$ intervals. The samples were agitated throughout the heating period to maintain a starch suspension. Then, the samples were centrifuged at $1500 \mathrm{rpm}$ for $10 \mathrm{mins}$ and the supernatant was carefully drawn off. The weight of the paste was determined and used to calculate the swelling power as the weight of paste divided by the original weight of dry starch.

\section{9 Pasting properties}

The pasting profiles were analysed using a Newport Scientific Rapid Visco Analyser 4 (RVA-4) (Newport Scientific, Warriewood, Australia) (Hasmadi et al., 2010). A total of $2.5 \mathrm{~g}$ of the sample was added with $25.5 \mathrm{~g}$ distilled water followed by mixing in the canister and placing in RVA. The suspension was kept at $25^{\circ} \mathrm{C}$ for 2 mins before heat to $95^{\circ} \mathrm{C}$ for 6 mins at $13.5^{\circ} \mathrm{C} / \mathrm{min}$ and keep at $95^{\circ} \mathrm{C}$ for 3 mins. Further, it was cooled to $25^{\circ} \mathrm{C}$ for $14^{\circ} \mathrm{C} / \mathrm{min}$ for 6 mins and keeps at 25 mins for 2 mins. From the RVA plots, the peak viscosity and final viscosity are determined. The average value is obtained by three repetition measurements.

\subsection{Gelatinization properties}

The starch gelatinization properties were measured using a Perkin Elmer Pyris 7 DSC (Perkin-Elmer Co., Norwalk, CT) as described by Hasmadi et al. (2010). A total of $3.0 \mathrm{mg}$ of the sample with $7.0 \mathrm{mg}$ of distilled water was hermetically sealed in DSC pans and keep at room temperature for 12 hours. Further, the sample was scanned against an empty pan by heating from 5 to $95^{\circ} \mathrm{C}$ at $10{ }^{\circ} \mathrm{C} / \mathrm{min}$. The empty pan was used as a reference. Starch gelatinization parameters, given by DSC thermogram, are the onset temperature, the conclusion temperature, the peak temperature and the enthalphy.

\subsection{Retrogradation properties}

The starch retrogradation properties were measured using a Perkin Elmer Pyris 7 DSC. The sample pans containing the starches were kept at $4^{\circ} \mathrm{C}$ for one week to study retrogradation properties. The pans were heated at a rate of $10^{\circ} \mathrm{C} / \mathrm{min}$ from $40-110^{\circ} \mathrm{C}$ and cooled at the same rate to $40^{\circ} \mathrm{C}$. Enthalpy of retrogradation $\left(\Delta \mathrm{H}_{\text {ret }}\right)$ was calculated for the endotherms and the exotherms. Percentage of retrogradation $(\% \mathrm{R})$ was calculated as (enthalpy for retrogradation/enthalpy for gelatinization) $\mathrm{x} 100$.

\subsection{Statistical analysis}

All determinations were replicated three times; mean values and standard deviations were reported.

\section{Results and discussion}

\subsection{The percentage recovery of starch extraction}

A total of $17.8 \%$ of starch was extracted from young Tarap (Table 1). The amount recorded was higher than starch extracted from young breadfruit (14.3\%) (Akanbi et al., 2009) but lower than jackfruit seeds $(26.1 \%)$ as reported by Rengsutthi and Charoenrein, (2011). Starch extraction yield is influenced by the various methods of drying and starch extraction method. In addition, the amount of starch extracted is dependent on the maturity of the fruit, variations and climatic differences and agronomic crops as reported by Rahman et al. (1999).

Table 1. The percentage of starch extracted from unripe Tarap starch

\begin{tabular}{cc}
\hline Parameter & Percentage (\%) \\
\hline Extracted starch & $17.85 \pm 0.20$ \\
Total starch & $89.14 \pm 2.20$ \\
Resistance starch & $47.82 \pm 1.50$ \\
Digestible starch & $41.32 \pm 0.00$ \\
Amylose & $11.97 \pm 0.15$ \\
Amylopectin & $77.15 \pm 0.22$ \\
\hline
\end{tabular}

The mean value $(\mathrm{n}=3) \pm$ standard deviation

\subsection{Morphological characteristics of the Tarap starch granules}

Image of Tarap starch granules under SEM found 

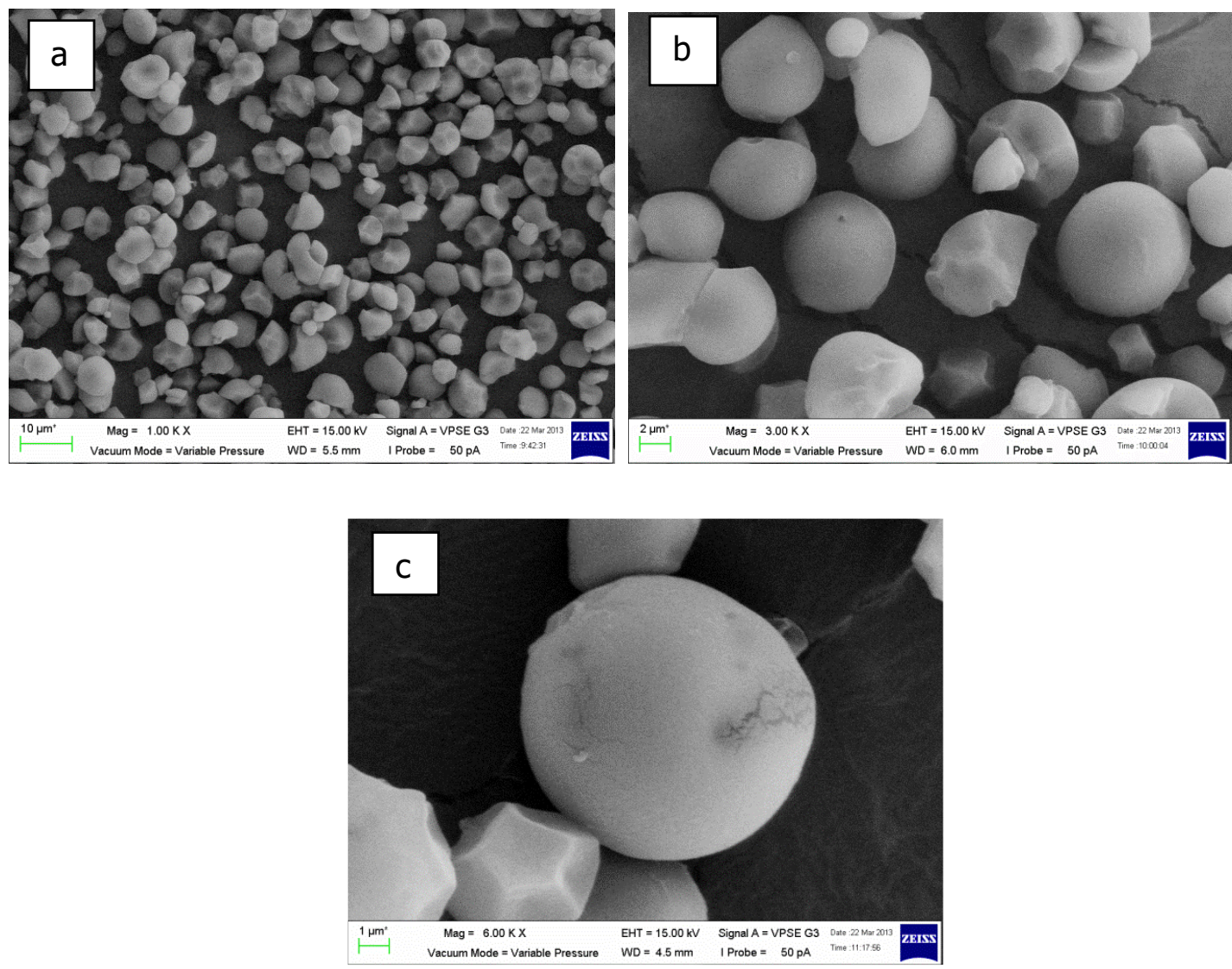

Figure 1. Microfigure SEM of Tarap starch; (a) 1,000 x, bar $=10 \mu \mathrm{m}$; (b) 3,000 x bar $=2 \mu \mathrm{m}$; (c) $6,000 \mathrm{x}$ bar $=1 \mu \mathrm{m}$.

that most of the granules were round and polygonal with a smooth surface as shown in Figure 1. The morphology is similar to corn starch granules as reported by Rengsutthi and Charoenrein (2011). Morphology of starch granules depends on the biochemistry of chloroplasts or amyloplasts refers to physicological of the plant (Badenhuizen, 1969). The observation of Tarap starch granules found that there are broken or damaged starch caused by the impact of the extraction process which similar finding was reported by Oates and Powell (1996).

The size of Tarap starch granules was in the range of $2.0-8.5 \mu \mathrm{m}$ with the mean size of $7.4 \mu \mathrm{m}$ for $300 \mathrm{starch}$ granules. The size is smaller than corn starch, 13.7- 13.9 $\mu \mathrm{m}$ and potato starch, 30.5 - $42.0 \mu \mathrm{m}$ (Singh et al., 2003; Rengsutthi and Charoenrein, 2011). According to Hoseney (1998), starch granules can be categorized into two groups, small size of cereal granules $(5-10 \mu \mathrm{m})$ and large granules size $(25-40 \mu \mathrm{m})$. The size and shape of starch granules also explain the basic features of plant biology (Delcour and Hoseney, 2010). Previous research has reported that the morphology and size of the starch granules influenced the physicochemical properties such as percentage of light penetration, swelling and water absorption capacity (Singh et al., 2003; Rengsutthi and Charoenrein, 2011). Thus, the average Tarap starches granules categorized as small granules that will improve the efficiency of the starch to absorb water and maximize the ability of starch to swell by the presence of water and heat temperatures that also affect the pasting properties of starch.

\subsection{Total starch content}

Tarap starch contains $89.14 \%$ of total starch and it is estimated the starch may contain $\approx 1.17 \%$ as gross amounts of ash, protein, and fat. The moisture content of $9.69 \%$ was obtained from the Tarap starch. Previous studies found that the amount of total starch of taro $(88.60 \%)$, yam $(81.72 \%)$ and sweet potato $(84.15 \%)$ reported by Aprianita et al. (2009) was lower than Tarap starch. Total starch content for jackfruit seed flour and young breadfruit were $77.8 \mathrm{~g} / 100 \mathrm{~g}$ and $98.6 \%$ as reported by Steve et al. (1995) and Tananuwong et al. (2002), respectively. Determination of total Tarap starch is important as the starch in food sources reported giving an impact on some functional properties such as its swelling, gelatinization, pasting properties, starch processing and the formulation of food. In addition, features such as the appearance of starch, size and structure of starch also affect the quality of food products (Tian et al., 1991). Therefore, the total Tarap starch might be affecting the functional properties of starch, which also depends on the structural characteristics and the ratio of macromolecules present in the starch.

\subsection{Amylose and amylopectin content}

The amylopectin content of Tarap starch is $86.55 \%$ which is in agreement with the value reported by Akanbi 
et al. (2009) for breadfruit starch. Amylose and amylopectin determination showed a composition of $77.15 \%$ and $11.97 \%$, respectively. The result obtained is showing similar trends as reported by Akanbi et al. (2009). Amylose content in Tarap starch is lower than unripe banana starch, $20.00-25.00 \%$, corn starch, $24.30 \%$, potato starch, $28.08 \%$, and jackfruit seed starch, $32.14 \%$ (Rengsutthi and Charoenrein, 2011). This clearly shows that Tarap starch is high in amylopectin where it is should be suitably used as a thickener, adhesive agent and a stabilizing agent to provide a good texture in the food product. In addition, low amylose ratio in Tarap starch will allow the starch absorbs more water and swelling well at high temperatures and might be good in pasting properties. Therefore, Tarap starch tends to be sticky and vicious as compaction in food processing as adhesives and thickeners. In term of health, the high amylopectin content in starch was reported to be able to increase the amount of the hormone insulin in the human body (Behall and Howe, 1998).

\subsection{Resistant starch content}

Tarap starch contained $47.82 \%$ of resistant starch with the ratio of resistant starch to total starch is 1: 2 . The previous study found that the amount of resistant starch in taro starch (44.98\%) was lower than the starch in Tarap (Aprianita et al., 2009). Resistant starch for corn starch, potato starch and tapioca starch were $7.83 \%$, $79.30 \%$, and $80.80 \%$ (Chen et al., 2010). Total resistant starch in Tarap starch is higher than jackfruit seed starch (26.99\%) (Phrukwiwattanakul et al., 2014) and other sources such as rice grains $(0.60 \%)$, and wheat flour $(0.60 \%)$ (Liu et al., 2006). Many studies in humans show that resistant starch can have positive health benefits such as lower blood sugar levels, reduce insulin secretion and improve digestion (Fuentes-Zaragoza et al., 2010).

\subsection{In vitro starch digestibility}

Results for Tarap starch in vitro starch digestibility at 30,90, 120 and 180 mins are based on the amount of glucose produced, mg per $100 \mathrm{~g}$ of the sample are shown in Table 1. The total percentage of digestible starch found in Tarap starch was $41.32 \%$ where the value is lower than digestible starch present in taro starch (51.22\%) and potato starch (98.95\%) (Aprianita et al., 2009). In addition, Tarap starch has lower rapid digestible starch at $30^{\text {th }}$ min $(6.58 \%)$ compared to slow digestible starch at $120^{\text {th }} \min (33.25 \%)$ (Table 2). This shows Tarap starch required a longer time to complete the enzymatic hydrolysis and the digested rate increased for slow digestible starch that is good for digestive purposes. The previous study also found that the resistant starch content of the samples obtained by hydrolysis method (Englyst et al., 1992) showed no significant difference $(\mathrm{p}>0.05)$ with the values obtained by the AOAC (2000) and AACC (2000) methods. This indicates that both the data collected is accurate and persist. Tarap starch was found to have a relatively high resistant starch, which also contributes to a good digestive system.

Table 2. Percentage of in vitro starch digestibility of unripe Tarap starch at 30, 90,120 and 180 minutes

\begin{tabular}{ccc}
\hline Parameter & Digestibility reference & in vitro digestibility (\%) \\
\hline RDS & 30 & $6.58 \pm 1.05$ \\
SDS & 120 & $33.25 \pm 2.11$ \\
RS & 180 & $47.40 \pm 1.16$ \\
pGI & 90 & $56.20 \pm 0.70$ \\
DSI & - & $6.65 \pm 0.45$ \\
\hline
\end{tabular}

The mean value $(n=3) \pm$ standard deviation. $\mathrm{RDS}=$ fast digestible starch, SDS = slowly digestible starch; RS = resistant starch, DSI = Index of starch digestion, DSI $=($ RDS / Starch total) x 100

Predict glycemic index (PGI) value measured based on the percentage of digestible starch obtained at the $90^{\text {th }}$ minute. Values obtained $(56.20 \%)$ was less than $70 \%$ of the glycemic index (GI) and categorized as medium glycemic content (Allen et al., 2012). According to Chiu et al. (2011), the GI is very important information in any foods that high in carbohydrates and low intake of GI values will give better health. In addition, the digestible starch index (DSI) of Tarap starch is low as the starch fraction that can be rapidly digested and hydrolyzed is lower than the total starch. Therefore, it can be concluded that Tarap starch has good nutritional value with the benefit of resistant starch and high in slowly digestible starch, medium in glycemic index value and low digestibility index.

\subsection{Swelling capability}

Figure 2 depicts the swelling capacity of Tarap starch at $60^{\circ} \mathrm{C}, 70^{\circ} \mathrm{C}, 80^{\circ} \mathrm{C}$ and $90^{\circ} \mathrm{C}$. The swelling capacity of Tarap starch increases with increase in temperature. This is in agreement with findings of Adebowale et al. (2005). Termination of hydrogen bonds between molecules begins at temperatures below $70^{\circ} \mathrm{C}$ resulted in enhancing the development of starch. This explains the increase of swelling as soon as the water is absorbing (De la Torre-Gutiérrez et al., 2008). Starch molecules bind with water molecules through hydrogen bonding. Thus, when the bond between the hydrogen and the starch molecules disintegrate, the hydrogen replaced by hydrogen bonds and water after gelatinization process.

Generally, amylose dissolves in water at elevated temperatures. As the temperature rises, gelatinization occurred, the starch granules ruptured, and amylose 
released out of the granules. This explains that at $90^{\circ} \mathrm{C}$, more amylose starch released (Akanbi et al., 2009; Rengsutthi and Charoenrein, 2011). Other factors were also reported the presence of lipids (Galliard and Bowler, 1987) and low protein will enhance the swelling and solubility of starch granules (Singh et al., 2003) however not determined in this study.

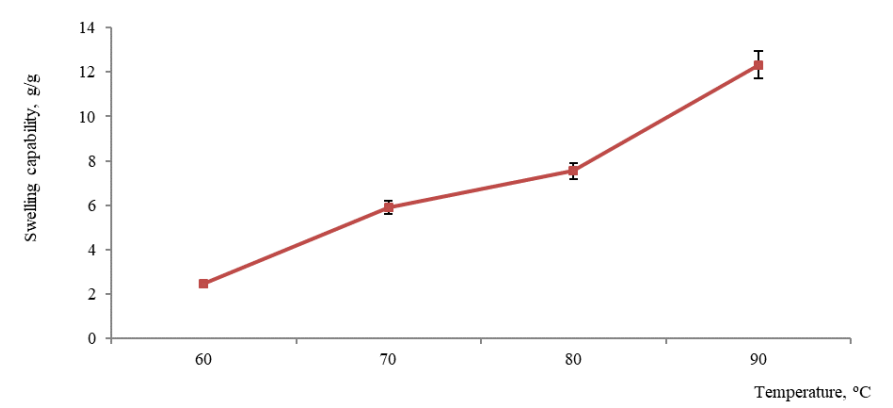

Figure 2. Swelling capability of Tarap starch at different temperatures

\subsection{Pasting properties}

Studies on the pasting properties of Tarap starch was carried out using RVA and the results are shown in Figure 3. Viscosity parameters determined during the swelling process as the starch is pasting and the soluble material released from starch granules (Sandhu and Singh, 2007). It was found that the pasting peak temperature of Tarap starch is $73.50^{\circ} \mathrm{C}$ occurred at 6.52 minutes (Table 3). This is influenced by the low amylose content that gives good pasting development as reported by Rengsutthi and Charoenrein (2011). However, the temperature is lower than jackfruit seeds starch $\left(85.83^{\circ} \mathrm{C}\right)$ reported by Mukprasit and Sajjaanantakul (2004). This is because the jackfruit seed starch granules contained high amylose which required high temperature for the starch granules to burst out before forming a paste. This also led to a slower peak time ( $8.74 \mathrm{mins})$ compared to Tarap starch. Thus, Tarap starch required moderately high energy and can be cooked quickly as compared to jackfruit seeds starch.

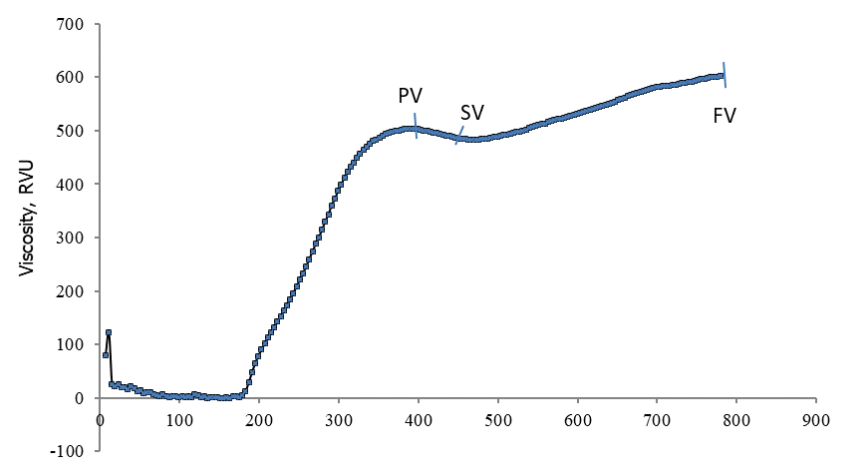

Figure 3. Pasting properties of Tarap starch. PV $=$ Peak viscosity, $\mathrm{SV}=$ Setback viscosity, $\mathrm{FV}=$ Final viscosity.

The maximum viscosity (PV) of Tarap starch found is higher than jackfruit seed starch, 432.43 RVU (Mukprasit and Sajjaanantakul, 2004) and cassava starch (223.88 RVU) (Rengsutthi and Charoenrein, 2011), which shows the suitability of the starch acts as a thickener. The factors that affect the peak viscosity of Tarap starch are its swelling capability and the possible existence of hydrophobic interaction effects. This was agreed by Singh et al. (2006) that there is a positive correlation between peak viscosity and its swelling capability. Hydrophobic interactions occur when the presence of the hydrophilic component is low in starch, such as lack of interaction between the protein and water molecules.

In addition, the final viscosity (FV) (602 RVU) of the Tarap starch found to be lower than potato starch (695.30 RVU) but higher than jackfruit seed starch (39.67 RVU) and cassava starch (66.25 RVU) (Rengsutthi and Charoenrein, 2011). Final viscosity measured the ability of the starch to form viscous paste after cooking and cooling.

The setback viscosity (SV) of Tarap starch was 482.70 RVU, higher than the value recorded for commercial starches, i.e wheat and corn but lower than potato, sweet potato and cassava, as reported by Li et al. (2014). According to Charles, (2004), the setback is referred to as the degree of re-association between the starch molecules involving amylose. The set back value is reflecting the degree of retrogradation of a starch paste. High amylose will accelerate retrogradation than low amylose starch (Sriroth and Piyachomkwan, 2003). As Tarap starch low in amylose, the tendency to retrograde is slower compared to other native starch such as corn starch, rice starch and wheat starch (Jane et al., 1999).

The final viscosity of Tarap starch was determined to find out the ability of starch to form a viscous paste. It is indicated by the alignment of the amylose molecules during the cooling period after gelatinization and a formation of a gel network. The value obtained 602.20 RVU was higher than jackfruit seed starch (489.21 RVU) (Mukprasit and Sajjaanantakul, 2004). Tarap starch molecules tend to clump together especially during retrogradation. According to Sandhu and Singh (2007), the final viscosity, peak viscosity, viscosity and setback viscosity of starch has a positive correlation with the swelling power as similar to the Tarap starch properties.

\subsection{Gelatinization characteristics}

Results on the gelatinization characteristics of Tarap starch using DSC with ratio water to starch, 3:1 as shown in Table 3. Tarap starch was found to have lower onset 
Table 3. Thermal properties of unripe Tarap starch

\begin{tabular}{lcc}
\hline Parameter & Gelatinization & Retrogradation \\
\hline Onset temperature, ${ }^{\circ} \mathrm{C}$ & $71.63 \pm 0.08$ & $59.81 \pm 0.11$ \\
Peak temperature, ${ }^{\circ} \mathrm{C}$ & $74.56 \pm 0.04$ & $62.15 \pm 0.15$ \\
Conclusion temperature, ${ }^{\circ} \mathrm{C}$ & $78.24 \pm 0.10$ & $66.35 \pm 0.08$ \\
Transition temperature, ${ }^{\circ} \mathrm{C}$ & $6.69 \pm 0.04$ & $6.53 \pm 0.03$ \\
Enthalpy energy, $\mathrm{J} / \mathrm{g}$ & $11.50 \pm 0.05$ & $3.74 \pm 0.12$ \\
\% Retrogradation & & $32.52 \pm 0.02$ \\
\hline
\end{tabular}

Mean $(n=3) \pm$ standard deviation, \% Retrogradation = Ratio of retrogradation enthalpy to gelatinization enthalpy.

temperature $\left(71.63^{\circ} \mathrm{C}\right)$ than yam starch $\left(75.00^{\circ} \mathrm{C}\right)$, taro starch $\left(76.80^{\circ} \mathrm{C}\right)$ and jackfruit seed starch $\left(82.92^{\circ} \mathrm{C}\right)$ but higher than potato starch $\left(61.55^{\circ} \mathrm{C}\right)$ and tapioca starch $\left(63.00^{\circ} \mathrm{C}\right)$ (Gunaratne and Hoover, 2002; Peroni et al., 2006; Kittipongpatana and Kittipongpatana, 2011). The gelatinization temperature is dependent on the shortchain branches of amylopectin (Jane et al., 1999).

The peak temperature obtained is an indicator of the content of amylopectin crystallization where the quality can be measured in terms of the length of the double helix (Singh et al., 2003). The gelatinization peak temperature of the Tarap starch is lower than the jackfruit seed starch $\left(86.01^{\circ} \mathrm{C}\right.$ ) (Kittipongpatana and Kittipongpatana, 2011), and yam starch $\left(83.00^{\circ} \mathrm{C}\right)$ but higher than cassava starch $\left(71.50^{\circ} \mathrm{C}\right)$ and potatoes starch $\left(66.3^{\circ} \mathrm{C}\right)$ (Gunaratne and Hoover, 2002). Normally, the high gelatinization peak temperature was influenced by the architecture and long double helix which requires high temperatures to break the bond completely (Karim et al., 2000).

The gelatinization temperature range of Tarap starch $\left(71.63-78.24^{\circ} \mathrm{C}\right)$ was higher than the gelatinization temperature range reported by Peroni et al. (2006) for cassava starch $\left(61.55-72.94^{\circ} \mathrm{C}\right)$ and potato starch $(62.85$ - $\left.77.91^{\circ} \mathrm{C}\right)$ as well as potato $\operatorname{starch}\left(59.60-76.00^{\circ} \mathrm{C}\right)$ (Gunaratne and Hoover, 2002), but was lower than jackfruit seed starch $\left(82.92-91.23^{\circ} \mathrm{C}\right)$, yam starch $(75.0$ $\left.-91.2^{\circ} \mathrm{C}\right)$ and taro starch $\left(76.8-95.2^{\circ} \mathrm{C}\right)$ (Gunaratne and Hoover, 2002; Kittipongpatana and Kittipongpatana, 2011).

The difference in gelatinization temperature of starch reported influenced by several factors, i) the molecular structure of amylopectin in terms of amylopectin branch chain length and, ii) the composition of starch in terms of the ratio of amylose to amylopectin content of complex lipids, chain amylose and phosphorus content, and iii) crystallization of amorphous granules (Gunaratne and Hoover, 2002). Gelatinization temperature of Tarap starch is high compared to cassava starch and sweet potato starch reported by Peroni et al. (2006) shows that there's a strong bond in Tarap starch granules. Tarap starch found to have high amylopectin that leads to high molecular crystallization.
The study also found that gelatinization enthalpy of Tarap starch $(11.50 \mathrm{~J} / \mathrm{g})$ was in the range of normal enthalpy of starch that is $10-20 \%$ (Eliasson and Gudmundsson, 1996). The enthalpy for tapioca starch, sweet potato and jackfruit seeds starch were reported to be $10.4 \mathrm{~J} / \mathrm{g}, 12.9 \mathrm{~J} / \mathrm{g}$ and 15:19 J/g, respectively (Peroni et al., 2006; Kittipongpatana and Kittipongpatana, 2011). In addition to measuring the quality and quantity of crystallization, enthalpy is an indicator of the loss of molecular order in starch granules (Singh et al., 2003). According to Gunaratne and Hoover (2002), the molecular structure of amylopectin and the layout of the granules is a key factor in a difference starch gelatinization characteristics. The higher the amylopectin content, the increasing the crystallization of starch granules and hence more energy is required to break the bond amylopectin.

\subsection{Retrogradation properties}

The molecular interactions (hydrogen bonding between starch chains) that occur after cooling of the gelatinized starch paste are known as retrogradation. The study on the retrogradation properties of Tarap starch was conducted by DSC as shown in Table 2. Degree of retrogradation of Tarap starch obtained is $32.52 \%$. The value is lower than a few starches such as potato starch (43.40\%), corn starch $(47.00-47.60 \%)$ and wheat starch (33.70\%) reported by Jane et al. (1999). The retrogradation percentage of starch is typically lower than the gelatinization enthalpy (Karim et al., 2000). The retrogradation temperature range for Tarap starch is higher than sweet potato starch $\left(42.04-66.28^{\circ} \mathrm{C}\right)$ and retrograded cassava starch $\left(42.73-61.98^{\circ} \mathrm{C}\right)$ with the enthalpy of $6.4 \mathrm{~J} / \mathrm{g}$ and $2.7 \mathrm{~J} / \mathrm{g}$, respectively as reported by Peroni et al. (2006). However, the retrogradation enthalpy of Tarap starch $(3.74 \mathrm{~J} / \mathrm{g})$ is higher than cassava starch reported by Peroni et al. (2006). The transition temperatures of retrogradation were found to be lower than the gelatinization temperatures. This might be due to the fact that recrystallization of amylopectin branched chains occurred in a less ordered manner in stored gels, as it is present in native form. 


\section{Conclusion}

Results from the study showed that Tarap starch has a lot of potential in the food industry, especially its uses as a thickener and binding agent in the food systems. This study suggested that young Tarap fruit starch has a good potential for food formulation because of its low in amylose and high in amylopectin. The high amylopectin presents in young Tarap fruit starch promotes very useful in many food and industrial applications especially where high thickening power is desired. Tarap starch also has high in SDS and less than $70 \%$ of glycemic index value that is beneficial in health, especially in the digestive system.

\section{Conflict of Interest}

The authors declare no conflicts of interest.

\section{Acknowledgements}

This work was supported by research Grants (Projects ERGS0003-STWN-1/2011). The authors thank Malaysian Education Department and Faculty of Food Science and Nutrition, Universiti Malaysia Sabah, Malaysia for providing all the laboratories facilities and technical assistance.

\section{References}

AACC International. (2000). Approved methods of the American Association of Cereal Chemists. 10th ed. St. Paul: American Association of Cereal Chemists.

Abu Bakar, M.F., Mohamed, M., Rahmat, A. and Fry, J. (2009). Phytochemicals and antioxidant activity of different parts of bambangan (Mangifera pajang) and tarap (Artocarpus odoratissimus) Food Chemistry, 113(2), $479-483 . \quad$ https:// doi.org/10.1016/j.foodchem.2008.07.081

Adebowale, K.O., Olu-Owolabi, B.I., Olawumi, E.K. and Lawal, O.S. (2005). Functional properties of native, physically and chemically modified breadfruit (Artocarpus artilis) starch. Indian Crop Production, 21(3), 343-51. https://doi.org/10.1016/ j.indcrop.2004.05.002

Agboola, S.O., Akingbala, S.O. and Oguntimein, O.B. (1991). Physicochemical and functional properties of LOW DS cassava starch acetates and citrates. Starch/Stärke, 43, 62-66. https://doi.org/10.1002/ star.19910430207

Akanbi, T.O., Nazamid, S. and Adebowale, A.A. (2009). Functional and pasting properties of a tropical breadfruit (Artocarpus altilis) starch from Ile-Ife, Osun State, Nigeria. International Food Research Journal, 16, 151-157.
Allen, J.C., Corbitt, A.D., Maloney, K.P., Butt, M.S. and Truong, V.D. (2012). Glycemic index of sweet potato as affected by cooking methods. Open Nutrition Journal, 6, 1-11. https:// doi.org/10.2174/1874288201206010001

AOAC. (2000). Association of Official Analytical Chemists Official Method of Analysis. 13th ed. Washington: Association of Official Analytical Chemists.

Aprianita, A., Purwandari, U., Watson, B. and Vasiljevic, T. (2009). Physico-chemical properties of flours and starches from selected commercial tubers available in Australia. International Food Research Journal, 16, 507-520.

Badenhuizen, N.P. (1969). The biogenesis of starch granules in higher plants. New York: Appleton Crofts.

Behall, K.M. and Howe, J.C. (1995). Effect of long-term consumption of amylose vs amylopectin starch on metabolic variables in human subjects. The American Journal of Clinical Nutrition, 61(2), 334340. https://doi.org/10.1093/ajcn/61.2.334

Charles, A.L. (2004). Some physical and chemical properties of starch isolates of cassava genotypes. Starch/Stärke, 56(9), 413-418. https:// doi.org/10.1002/star.200300226

Chen C.J., Shen Y.C. and Yeh A.I. (2010). Physicochemical characteristics of media-milled corn starch. Journal Agriculture and Food Chemistry, 58, 90839091. https://doi.org/10.1021/jf1020945

Chiu, C.J., Liu, S., Willett, W.C., Wolever, T.M.S, Brand-Miller, J.C., Barclay, A.W. and Taylor, A. (2011). Informing food choices and health outcomes by use of the dietary glycemic index. Nutrition Review, 69(4), 231-242. https://doi.org/10.1111/ j.1753-4887.2011.00382.x

Chung, H.J., Lim, H.S. and Lim, S.T. (2006). Effect of partial gelatinization and retrogradation on the enzymatic digestion of waxy rice starch. Journal of Cereal Science, 43, 353-359. https:// doi.org/10.1016/j.jcs.2005.12.001

De la Torre- Gutiérrez L., Chel-Guerrero, L.A. and Betancur-Ancona, D. (2008). Functional properties of square banana (Musa balbisiana) starch. Food Chemistry, 106(3), 1138-1144. https:// doi.org/10.1016/j.foodchem.2007.07.044

Delcour, J.A. and Hoseney, R.C. (2010). Principles of Cereal Science and Technology. St. Paul, MN, USA: AACC Int., Inc. https:// doi.org/10.1094/9781891127632

Eliasson, A.C. and Gudmundsson, M. (1996). Starch: Physicochemical and functional aspects. In Eliasson, 
A.C. (Ed). Carbohydrates in Food., p. 431-503. New York: Marcel Dekker.

Englyst, H.N., Kingman, S.M. and Cummings, J.H. (1992). Classification and measurement of nutritionally important starch fractions. European Journal of Clinical Nutrition, 46(Suppl. 2), 33-50.

Fuentes-Zaragoza, E., Riquelme-Navarrete, M., SánchezZapata, J.E. and Pérez-Álvarez, J.A. (2010). Resistant starch as functional ingredient: A review. Food Research International, 43(4): 931-942. https://doi.org/10.1016/j.foodres.2010.02.004

Galliard, T. and Bowler, P. (1987). Morphology and composition of starch. In Galliard, T. (Ed). Starch: Properties and Potential. New York: John Wiley and Sons.

Gunaratne, A. and Hoover, R. (2002). Effect of heatmoisture treatment on the structure and physicochemical properties of tuber and root starches. Carbohydrate Polymers, 49(4), 425-437. https://doi.org/10.1016/S0144-8617(01)00354-X

Haralampu, S.G. (2000). Resistant starch: a review of the physical properties and biological impact of RS3. Carbohydrate Polymers, 41(3), 285-292. https:// doi.org/10.1016/S0144-8617(99)00147-2

Hasmadi, M., Madian, A.H. and Sandra E.H. (2010). Physicochemical properties of commercial semisweet biscuit. Food Chemistry, 121(4), 1029-1038. https://doi.org/10.1016/j.foodchem.2010.01.043

Hoseney, R.C. (1998). Principles of Cereal Science and Technology. 2nd ed. St. Paul, MN: AACC International.

Jane, J., Chen, Y.Y., Lee, L.F., McPherson, A.E., Wong, K.S., Radosavijevic, M. and Kasemsuwan, T. (1999). Effects of amylopectin branch chain length and amylose content on the gelatinization and pasting properties of starch. Cereal Chemistry, 76(5), 629-637.

https://doi.org/10.1094/

CCHEM.1999.76.5.629

Karim, A.A., Norziah, M.H. and Seow, C.C. (2000). Methods for the study of starch retrogradation. Food Chemistry, 7(1), 9-36. https://doi.org/10.1016/S0308 -8146(00)00130-8

Kittipongpatana, O.S. and Kittipongpatana, N. (2011). Preparation and physicochemical properties of modified jackfruit starches. LWT - Food Science and Technology, 44(8), 1766-1773. https:// doi.org/10.1016/j.lwt.2011.03.023

Lehmann, U. and Robin, F. (2007). Slowly digestible starch - Its structure and health implications: A review. Trends in Food Science and Technology, 18 (7), 346-355. https://doi.org/10.1016/ j.tifs.2007.02.009
Li, S., Zhang, Y., Wei, Y., Zhang, W. and Zhang, B. (2014). Thermal, pasting and gel textural properties of commercial starches from different botanical sources. Journal Bioprocessing and Biotechnique, 4, 161. https://doi.org/10.4172/2155-9821.1000161

Liu, H.S., Yu, L., Xie, F.W. and Chen, L. (2006.) Gelatinization of corn starch with different amylose/ amylopectin content. Carbohydrate Polymers, 65(3), 357-363.

McCleary, B.V., Gibson, T.S. and Mugford, D.C. (1997). Measurement of total starch in cereal products by amyloglucosidase - a-amylase method: Collaborative study. Journal of Association Official Analytical Chemistry, 80, 571-579.

McCleary, B.V., McNally, M., Rossiter, P., Aman, P., Amrein, T. and Arnouts, S. (2002). Measurement of resistant starch by enzymatic digestion in starch and selected plant materials: Collaborative study. Journal of AOAC International, 85(5), 1103-1111.

Mukprasit, A. and Sajjaanantakul, K. (2004). Physicochemical properties of flour and starch from jackfruit seeds (Artarpus heterophyllus Lam.) compared with modified starches. International Journal of Food Science and Technology, 39(3), 271-276. https:// doi.org/10.1111/j.1365-2621.2004.00781.x

Noorfarahzilah, M., Mansoor, A.H. and Hasmadi, M. (2017). Proximate composition, mineral content and functional properties of Tarap (Artocarpus odoratissimus) seed flour. Food Research, 1(3), 8996. https://doi.org/10.26656/fr.2017.3.025

Nwokocha, L.M. and Williams, P.A. (2011). Structure and properties of Treculia africana, (Decne) seed starch. Carbohydrate Polymers, 84(1), 395401. https://doi.org/10.1016/j.carbpol.2010.11.053

Oates, C.G. and Powell, A.D. (1996). Food chemistry: Bioavailability of carbohydrate material stored in tropical fruit seeds. USA: Elsevier. https:// doi.org/10.1016/0308-8146(95)00209-X

Othaman, Z., Al-Assaf, S. and Hassan, O. (2010). Molecular characterisation of sago starch using gel permeation chromatography multi-angle laser light scattering. Sains Malaysiana, 39(6), 969-973.

Peroni, F., Rocha, T. and Franco, C. (2006). Some structural and physicochemical characteristics of tuber and root starches. Food Science Technology International, 12(6), 505-513. https:// doi.org/10.1177/1082013206073045

Phrukwiwattanakul, P., Wichienchotand, S. and Sirivongpaisal, P. (2014). Comparative studies on physico-chemical properties of starches from jackfruit seed and mung bean. International Journal of Food Properties, 17(9), 1965-1976. https:// 
doi.org/10.1080/10942912.2013.775151

Rahman, M.A., Nahar, N., Mian, A.J. and Mosihuzzaman, M. (1999). Variation of carbohydrate composition of two forms of fruit from jack tree (Artocarpus heterophyllus L) with maturity and climatic conditions. Food Chemistry, 65(1), 9197. https://doi.org/10.1016/S0308-8146(98)00175-7

Rengsutthi, K. and Charoenrein, S. (2011). Physicochemical properties of jackfruit seed starch (Artocarpus heterophyllus) and its application as a thickener and stabilizer in chilli sauce. LWT-Food Science and Technology, 44(5), 1309-1313. https:// doi.org/10.1016/j.lwt.2010.12.019

Sandhu, S.K. and Singh, N. (2007). Some properties of corn starches II. Physicochemical, gelatinization, retrogradation, pasting and gel textural properties. Food Chemistry, 101(4), 1499-1507. https:// doi.org/10.1016/j.foodchem.2006.01.060

Singh, N., Kaur, L., Sandhu, K.S., Kaur, J. and Nishinari, K. (2006). Relationships between physicochemical, morphological, thermal, rheological properties of rice starches. Food Hydrocolloids, 20(4), 532-542. https:// doi.org/10.1016/j.foodhyd.2005.05.003

Singh, N., Singh, J., Kaur, L., Sodhi, S.N. and Gill, S.B. (2003). Morphological, thermal and rheological properties of starches from different botanical sources. Food Chemistry, 81(2), 219-231. https:// doi.org/10.1016/S0308-8146(02)00416-8

Sriroth K. and Piyachomkwan, K. (2003). Starch Technology. 3rd ed. Bangkok: Kasetsart University press.

Steve, R.A., Adewusi A., Akpobome, U.I. and Osuntogun, B.A. (1995). Studies on the carbohydrate content of breadfruit (Artocarpus communis Forst) from Southwestern Nigeria. Journal of Starch, 47(8), 289-294. https:// doi.org/10.1002/star.19950470802

Svegmark, K. and Hermansson, A.M. (1993). Microstructure and rheological properties of composites of potato starch granules and amylose: A comparison of observed and predicted structure. Food Structure, 12, 181-193.

Tananuwong K, Tulyathan V., Songjinda P. and Jaiboon N. (2002). Some physico-chemical properties of jackfruit seed flour and starch. Science Asia, 28, 341. https://doi.org/10.2306/scienceasia15131874.2002.28.037

Tattiyakul, J., Pradipasena, P. and Asavasaksakul, S. (2007). Taro colocasia esculenta (L.) Schott amylopectin structure and its effect on starch functional properties. Starch, 59(7), 342-347. https://doi.org/10.1002/star.200700620

Tian, S.J., Richard, J.E. and Blanshard, J.M.V. (1991). Physicochemical properties of sweet potato starch. Journal of Food and Agriculture, 57(4), 286-289. https://doi.org/10.1002/jsfa.2740570402

Vaclavik, V.A. and Christian, E.W. (2008). Essentials of food science. 3rd ed. New York, USA: Springer.

Wang, L.Z., and White, P.J. (1994). Structure and physicochemical properties of starches from oats with different lipid content. Cereal Chemistry, 71, 443-450.

Wickramasinghe, H.A.M., Takigawa, S., Endo, C.M., Yamauchi, H. and Noda, T. (2009). Comparative analysis of starch properties of different root and tuber crops of Sri Lanka. Food Chemistry, 112(1), 98-103. https://doi.org/10.1016/ j.foodchem.2008.05.046

Yuan, Y., Zhang, L., Dai, Y. and Yu, J. (2007). Physicochemical properties of starch obtained from Dioscorea nipponica makino comparison with other tuber starches. Journal of Food Engineering, 82(4), $436442 . \quad$ https://doi.org/10.1016/ j.jfoodeng.2007.02.055 